\title{
Uma filosofia que seja o estremecer de um som: sobre o sentido em Jean-Luc Nancy
}

Paola Ghetti

UNICAMP

\begin{abstract}
Resumo
$\mathrm{O}$ artigo pretende, em primeiro lugar, analisar a relação que Jean-Luc Nancy estabelece entre a filosofia e o som, refletindo sobre o modo como o sentido sensível articula o inteligível. Em seguida, visa compreender a noção de "ressonância" desenvolvida pelo autor a partir das especificidades do que seriam o realismo e a fenomenologia em sua obra.
\end{abstract}

Palavras-chave: sentido; escuta; ressonância.

\section{Résumé}

Cet article vise, d'une part, d'analyser la relation que Jean-Luc Nancy établit entre la philosophie et le son, ce qui reflète la façon dont le sens sensible articule l'intelligible. Ensuite, cherche à comprendre le concept de «résonance» développé par l'auteur à partir de la spécificité de ce qui serait le réalisme et la phénoménologie dans leur travail.

Mots-clés: sens; écoute; résonance. 
1. "J'ai le sentiment de ne plus vouloir indéfiniment reprendre la besogne philosophique. Au fond, à la différance, je crois, de mon ami Alain Badiou, j’ai de moins en moins l'impression aujourd'hui d'avoir une philosophie, de savoir même ce qu'est la philosophie. Je veux être mené au bord d'autres écritures. Je ne peux quasiment plus écouter de musique classique. J'ai besoin de la musique qui s'écrit maintenant. Qu'y a-t-il dans cette musique? Une absence des formes toutes faites, une absence de conventions mélodiques, harmoniques. Il y a une tension vers la naissance du son, qui parfois frôle le bruit. J'aimerais faire de la philosophie qui soit juste le frémissement d'un son". CERF, Juliette. "Jean-

Luc Nancy, penseur du corps, des sens et des arts". Telerama, 07/2012.

\section{O sensível e o inteligível}

No que diz respeito às inclinações mais recentes da obra de Jean-Luc Nancy, uma declaração chama a atenção pelo desejo de distanciamento da filosofia. Trata-se da entrevista feita em 2012 para a revista "Telerama", do Le Monde, por Juliette Cerf. Nancy, na ocasião, diz:

Tenho o sentimento de não mais querer retomar indefinidamente o trabalho filosófico. No fundo, acredito que diferente de meu amigo Alain Badiou, tenho hoje cada vez menos a impressão de ter uma filosofia ou mesmo de saber o que é a filosofia. Quero ser levado à beira de outras escrituras. Quase já não posso escutar música clássica. Preciso da música que se escreve hoje. O que há nesta música? Uma ausência de formas prontas, uma ausência de convenções melódicas, harmônicas. Há uma tensão em direção ao nascimento do som que certas vezes raspa no ruído. Gostaria de fazer uma filosofia que fosse apenas o estremecimento de um som $^{1}$.

Se por um lado, sabe-se que declarações de um autor nem sempre são a melhor fonte para se pensar a obra, por outro, tendo em vista as publicações de Nancy ao longo dos últimos anos, compreende-se que a declaração acima expressa de forma contundente uma tendência a se afastar dos registros filosóficos do século $\mathrm{XX}$, construindo uma trajetória específica na filosofia francesa contemporânea.

Ainda que declare não querer retomar indefinidamente o trabalho da filosofia, Nancy registra que sua obra partiria dela para se aproximar de outras escrituras. A filosofia é vista como um limite, mas um limite levado às margens, estremecido. $\mathrm{A}$ articulação específica com a qual este estremecimento se remete à exterioridade é o que constitui a singularidade de cada um de seus textos, uma vez que se propõe um pensamento para fora das margens convencionais da filosofia. O que o interessaria, e o que a declaração atesta, seriam as particularidades da borda, bem como as da abordagem.

A declaração de Nancy, além da questão dos limites da filosofia, comporta outra perspectiva, a da dimensão sensível e material do pensamento. Para um primeiro olhar sobre o tema, basta retomar o final da citação, que insere na filosofia a urgência da realidade, no caso, da realidade enquanto sensação de um som: "gostaria de fazer uma filosofia que seja o estremecimento de um som".

É notável a incidência dessa dimensão sensível na obra de Nancy, tanto nas entrevistas mais destacadamente autorais quanto em suas publicações, especialmente a partir da segunda 
metade da década de noventa. Livros como $A$ escuta, cuja leitura é privilegiada aqui, mas também Corpus, $O$ peso de um pensamento, $A$ evidência do filme, $O$ olhar do retrato, $N$ us somos, escritos a partir deste período, são alguns exemplos dos modos de estar "à beira de outras escrituras" e articular o sentido neste movimento sensível, tal como expõe Nancy na entrevista. A necessidade de testar esses múltiplos modos de se relacionar com o sensível marca justamente a tentativa do autor em retraçar os contornos da filosofia na medida em que se aproxima de escrituras que se desenham na contemporaneidade 2 .

Sobre a relação entre o inteligível e a realidade sensível, Nancy argumenta, em $O$ peso de um pensamento, que o inteligível seria uma das formas através das quais o sensível se articula: "o inteligível é a sensibilidade na medida em que ela se apresenta a ela mesma: na medida em que ela se faz sentir aquilo que é o sentir" ${ }^{3}$, o que inscreveria o inteligível no domínio da questão do sentido. Sendo assim, a busca por ser levado “à beira de outras escrituras", mais do que um desejo de transformação epistemológica no sentido cognitivo, corresponderia a um movimento de engajamento do corpo e suas percepções. O sentido inteligível, portanto, sendo "a sensibilidade se apresentando a ela mesma”, se pesaria e se sentiria junto ao som, às imagens, às diferentes cores, texturas e densidades do mundo. Em suma, se pesaria de acordo com os sentidos, produzindo uma diversidade de acessos sensíveis, sejam eles de ordem sensorial, sensual ou sentimental.

O foco da questão, nesse ponto, não seria apenas o dos limites da filosofia, mas o de uma escrita e um pensamento que se articulam a partir da dimensão sensível se inserindo num determinado modo de existência. Nas palavras de Nancy, "o corpo suscita o pensamento, esta sensibilidade ao mundo como tal, à existência ou ao ser como aqueles que formam um acesso suplementar: aquele que abre todos os sentidos ao infinito"4. Em outras palavras, o sensível suscita o inteligível e o faz num movimento constante que não se completa ou finaliza produzindo uma significação ou uma informação, pois nesse caso, a operação deixaria de fazer "sentido". O sentido, pelo contrário, é dado a partir de um movimento bastante particular que o implica num remetimento e numa articulação infinita para fora de si, causando uma relação de excesso com aquilo que, por exemplo, se nomeia por significado, fenômeno e presença.

Sendo o sentido (enquanto percepção sensória e inteligível) marcado por esta força excedente - que impulsiona todo "si" para fora de "si" - toda percepção de mundo, dos regimes de sentido e seus compartilhamentos é exercida nesta pré-condição da articulação, a partir, por exemplo, do movimento, do ritmo, da cadência implicada em cada articulação do sentido.
2. Não será possível tratar detalhadamente do modo como Nancy se acerca de cada uma destas escrituras, estremecendo os contornos da filosofia a partir de cada contato específico, dada a extensão deste estudo. A reflexão irá portanto acercar-se da relação específica que o autor estabelece entre a filosofia e o som.

3. "l'intelligible est la sensibilité en tant qu'elle se présente à elle-même: en tant qu'elle se fait sentir ce que c'est que [sentir]". NANCY, JeanLuc. Le poids d'une pensée, l'approche, 2008, p. 211.

4. “[...] le corps suscite la pensée, cette sensibilité au monde comme tel, à l'existence ou à l'être comme tels qui forme l'accès supplémentaire: celui qui ouvre tous les sens à l'infini”. NANCY, Jean-Luc. "Making sense", 2011, p. 214. 
5. "En realité, je ne cesse de parler du timbre, et je cherche à timbrer mon discours de philosophe". NANCY, JeanLuc. À l'écoute, 2002, p. 76. Aqui, pode-se pensar num possível jogo com a palavra "timbre", que se remeteria tanto ao "timbre" da voz quanto ao "timbre" como carimbo ou marca no papel.
As questões de ritmo e frequencia temporal pensadas como modos através dos quais a realidade sensível se imprime no pensamento se aplicam igualmente às distinções físicas colocadas pelo timbre. Sendo caracterizado pelo conjunto de vibrações que se dão entre o corpo humano e as cordas vocais, o timbre se constitui como uma marca singular na voz. Neste caso, é interessante notar a tensão que Nancy estabelece, em A l'écoute, entre as marcas da voz e as marcas da escrita: "na verdade, eu não paro de falar de timbre e procuro timbrar meu discurso de filósofo" ${ }^{\prime}$.

$$
* * *
$$

Assim, no que diz respeito às relações que a filosofia estabelece com a música, as aproximações que Nancy faz entre o sensível e o inteligível ganham maior especificidade em $\dot{A}$ escuta. Em verdade, Nancy, no livro, não somente trata da música e sua relação com o sentido (sensível ou inteligível), como também sugere que os modos como se escuta o som impregnariam a existência de possibilidades de sentido. $\mathrm{O}$ estar "à beira de outras escrituras", neste caso, envolveria estar na iminência do sentido através do som. $\mathrm{O}$ autor então expõe o desejo de ruptura com a filosofia como ciência do ouvir (que estaria muito ligada às concepções formais) e a necessidade de se inserir na realidade presente, numa história em curso, destacando a música (ou a percepção do som, de modo mais amplo) nesta relação justa com o pensamento.

Já nas primeiras páginas, Nancy apresenta a questão que se coloca entre a filosofia e o som, através da ambiguidade entre os verbos escutar (écouter) e ouvir (entente). Se o primeiro designa um gesto que estaria do lado do sentido e do sentido como abertura e possibilidade, o segundo se remeteria à verdade, ao entendimento e ao acabamento. A contraposição apontada por Nancy é clara: aquele que escuta deixa ressoar as possibilidades de sentidos imbricados no som, abrindo-se a cada contexto diferente-mente; aquele que ouve compreende previamente o som a partir de uma convenção ou predeterminação, codificando o que já sabia antes e afastando a forma e o modo de emissão daquilo que se ouve. A filosofia é tomada com ressalva, sendo a princípio compreendida a partir do ouvir, quando Nancy se pergunta se ela não estaria submetendo à escuta algo que seria da ordem do ouvir. Ou ainda, se o filósofo não estaria neutralizando a "escuta" para poder assim filosofar.

As indagações, como destacado pelo próprio autor nas páginas seguintes, demonstram um comprometimento em pensar as relações que se estabelecem entre sentido (aquilo que se 
escuta na abertura do sentido) e verdade (aquilo que se ouve de modo previamente determinado) a partir do som. Assim, ao relacionar a filosofia ao ouvir (em contraposição ao escutar), ao mesmo tempo em que declara a necessidade de ser levado à beira de outras escrituras, Nancy está se colocando a tarefa de explorar os limites do pensamento e da própria filosofia, para que ela se aproxime do que seria a escuta, em vez do ouvir.

O peso da filosofia, ou o peso do pensamento, neste caso, se articularia a partir do peso do som exercido em cada corpo e em cada ouvido, produzindo sensações, sentimentos e estímulos sempre e a cada vez singulares. Esta relação de codependência que o inteligível tem com o sentimento e/ou sensorial pode ser também contemplada quando em outro momento Nancy sugere que as faculdades inteligíveis e abstratas se assemelham a uma "responsabilidade do sentido". Tal "responsabilidade" se manifestaria, segundo Nancy, muito perto do sentimento; de uma sensação que, se sentindo, se aprova ou desaprova.

\section{O sentido na ressonância}

Quanto à relação que a filosofia tem com o sentido, um ponto se destaca na declaração de Nancy. Note-se que ele não está dizendo querer fazer uma filosofia como o estremecer de um som, ou uma filosofia que seja o som enquanto tal, mas uma que seja o estremecer do som. Não se trata de uma filosofia que represente o estremecer ou que substitua a linguagem pelo som, mas de uma filosofia que seja o estremecer, realmente ou literalmente.

A partir do que Nancy propõe, o que se dá como pensamento não seria uma face inversa ou representativa da realidade sonora, mas tensiona e interage com essa realidade. Então, a relação específica que a filosofia estabelece com o som não se completaria ou finalizaria como uma instância em si, mas ressoaria infinitamente através dos "poros" ou "ouvidos" da filosofia, algo que acontece entre o pensamento e o som. Deste modo, a aproximação entre a filosofia e a dimensão sensível aponta não apenas para uma filosofia estremecida em seus limites mas para a compreensão de que a filosofia é alimentada pela força da realidade ou da materialidade da existência.

A reflexão comporta uma tendência que alguns críticos, como Ian James em The fragmentary demand (2012) e Derrida em Le toucher (2001) chamaram de realismo ou pós-realismo na obra de Nancy, embora esse tipo de realismo tenha pouca semelhança com o que tradicionalmente se compreende pelo 
6. "Le sujet de l'écoute ou le sujet à l'écoute n'est pas un sujet phénoménologique c'est-à-dire qu'il n'est pas un sujet philosophique et, qu'en definitive, il n'est peut-être aucun sujet sauf à être le lieu de la résonance, de sa tension et de son rebond infinis". NANCY, Jean-Luc. À l'écoute, 2002, p. 45. termo. A particularidade de tal realismo se colocaria especialmente por Nancy não compartilhar do conceito convencional de mímesis, tanto por romper com a noção de uma manifestação do fenômeno do som quanto pela precariedade da noção de sujeito, necessária na percepção de um fenômeno.

$* * *$

Possivelmente, uma forma de compreender essa espécie de realismo seria pôr em relevo seu ponto de partida mais especificamente fenomenológico e o modo como o autor o problematiza. Sendo a fenomenologia a área que reflete sobre a percepção sensível e sua relação com a consciência, dito de modo genérico, compreende-se que Nancy, em À l'écoute, estaria partindo desse domínio. Nancy não especifica sobre qual perspectiva ou qual autor da fenomenologia ele estaria se distanciando, mas registra que ela não seria suficiente para compreender o modo como o sentido sonoro ou a percepção sensível do som se dá:

O sujeito da escuta ou o sujeito à escuta não é um sujeito fenomenológico, o que quer dizer que ele não é um sujeito filosófico e que talvez ele não seja nenhum sujeito, senão sendo o lugar da ressonância, de sua tensão e sua repercussão infinita ${ }^{6}$.

Assim, a partida "fenomenológica" não se realiza por completo na medida em que Nancy não compartilha determinados preceitos fenomenológicos, como o de "sujeito fenomenológico", e o de "sujeito filosófico", pois o sujeito da escuta não é um sujeito consciente ou receptor de um fenômeno.

Neste ponto, a reflexão comporta não apenas a relação que Nancy faz da filosofia com o sensível, mas também a relevância do problema da subjetividade na relação com o som. Nancy remete-se à análise de Lacoue-Labarthe, em "O eco do sujeito", para dizer que aquilo que pode ser nomeado por "sujeito” apenas existe a partir de um engajamento sensível e um movimento infinito de articulação de si mesmo. Porém destaca que o que lhe interessa é aquilo que acontece antes de qualquer possível identificação especular ou figura visível.

Sem nos determos na comparação com Lacoue-Labarthe, o que então importaria, mais do que o lugar do sujeito ou da filosofia, é o modo como Nancy os compreende como lugares de ressonância do sentido; ou ainda, voltando à frase inicial, como o lugar do "estremecimento de um som".

Uma das contribuições específicas de À l'écoute, neste contexto, se coloca através do que Nancy nomeia por "ressonância 
fundamental" ou por "sujeito como caixa de ressonância". A formulação evidencia uma espacialidade complexa, trazendo a ideia de que o que quer que se considere "primeiro" ou "fundamental" será, desde sempre, atravessado por algo que lhe ultrapassa, tendo esse processo lugar no próprio corpo, que se pensa e se pesa num mesmo movimento. Se a demanda de realidade, na filosofia de Nancy, se exerce no movimento através do qual o sentido vem a ser, a relação específica com o som envolve a noção que ele desenvolve sobre a ressonância.

Como indica o fragmento no verso do livro, em lugar da intencionalidade do ato de escuta, que visaria um sentido final, ou ainda, em lugar das perguntas "o que é" ou "qual é" um corpo sonoro, no sentido de qual seria a sua verdade, o que estaria em jogo seriam as articulações feitas entre os sons sentidos e os diferentes timbres e ritmos que ressoariam em todos e em cada ouvido: "escute: é uma pele estendida sobre uma caixa-acústica, e algo lhe acerta ou belisca, te fazendo ressoar de acordo com seu timbre e a seu ritmo"7. É clara a intenção de Nancy de mostrar que a escuta não é apenas sonora, ou não é sonora em si mesma, não podendo por isso se reduzir a uma finalidade, mas envolve tanto o corpo como instância sensível na ressonância (efeito sentido e provocado pelas batidas do coração, pelo fluxo da respiração, etc.) quanto as faculdades abstratas do sentido.

A operação da escuta através da ressonância do sentido nos corpos, não sendo "sonora" em si mesma, está presente na escrita ou no texto, que modalizaria, por exemplo, sua dicção e seu timbre através desta escuta, tal como a citação que Nancy faz de Ponge: "nunca me ocorre escrever uma única frase se minha escritura não vier acompanhada de uma dicção e de uma escuta mental $(. . .)^{8}$ ". Neste caso, soma-se toda a questão que se abre entre o sonoro e o verbal, pelo modo como a escuta e a escrita se relacionam ao articularem o sentido. A relação entre os dois registros produz diferenças e um jogo de forças que, segundo Nancy, pode explicar a própria relação com o pensamento na pluralidade heterogênea das artes, como explica em Les Muses: "a pluralidade sensível e técnica das artes engaja o sentido inteligível”.

Assim, se o sensível suscita o inteligível, como mencionado anteriormente, ele o faz a partir de uma relação complexa consigo mesmo, na qual os registros sensoriais estão imersos na inevitável partilha que os une e separa a um só tempo, sejam eles o timbre, o ritmo ou o movimento. Deste modo, se há
7. “Écoute: c'est une peau tendue sur une chambre d'écho, et qu'un autre frappe ou pince, te faisant résonner; selon ton timbre et à son rythme". NANCY, Jean-Luc. À l'écoute, 2002 [contra-capa].

8. "Il ne m'arrive jamais d'écrire la moindre phrase que mon écriture ne s'accompagne d'une diction et d'une écoute mentales". NANCY, Jean-Luc. Les Muses, 1994/2001, pp. 67-68.

9. "La pluralité sensible et technique des arts engage le sens intelligible". NANCY, Jean-Luc. Les Muses, 1994/2001, p.52. 
singularidade ou dicção na escrita, é porque ela está imersa no espaço da partilha, no estremecimento que toca os sentidos na sua infinita pluralidade. 


\section{Referências}

CERF, Juliette. "Jean-Luc Nancy, penseur du corps, des sens et des arts”. Telerama, 07/2012.

NANCY, Jean-Luc. Les Muses. Paris: Galilée, 1994/2001.

. À l'écoute. Paris: Galilée, 2002.

. Le poids d'une pensée, l'approche. Strasbourg: La

Phocide, 2008.

"Making Sense", in: COLLINS, Lorna; RUSH, Elizabeth

(Orgs). Making sense. Berna: Peter Lang, 2011. 
